\title{
Relationship between Religiosity and Individual Economic Achievement: Evidence from South Kalimantan, Indonesia
}

\author{
Selamah Abdullah Yusof \\ Department of Economics, International Islamic University Malaysia \\ Mohammad Arif Budiman \\ Department of Accounting for Islamic Financial Institutions \\ Banjarmasin State Polytechnic, Indonesia \\ Ruzita Mohammad Amin \\ Department of Economics, International Islamic University Malaysia
}

\begin{abstract}
This study investigates the effect of religiosity on economic development or achievement of individuals in South Kalimantan, Indonesia. This province is of interest as its people are viewed as highly religious but lagging in economic development. The study attempts to address the measurement issues found in earlier studies at the micro level of analysis by constructing a multi-dimensional measure of religiosity. This study considers five dimensions of religion, namely: ritualistic, experiential, ideological, consequential and intellectual. Apart from the construction of a multi-dimensional measure of religiosity, an indicator of economic wellbeing is formulated other than income. The results show that Muslims in South Kalimantan have a high level of religiosity and that those with higher level of religiosity are economically better-off. Education was also found to be a significant determinant of individual economic achievement. Hence, religion and education must be emphasized for economic progress especially for South Kalimantan which has a low level of education.
\end{abstract}

Keywords: Religiosity, South Kalimantan, Economic achievement.

JEL Classification: A12, A13, 012, Z12

KAUJIE Classification: B5, F4, H47, H87 


\section{Introduction}

Religion is an important aspect of human life. The term 'religion' derives from the Latin word 'religio' or 'religare' which means 'to bind'. It signifies belief in or obedience to some sacred and/or supernatural powers (Quinn, 2005, p. 180; Wilson \& Slavens, 1982, pp. 3-4). The term 'religiosity' which means 'the quality of being religious' has also been used frequently in literature. It encompasses having commitment to religion that includes not only the belief system but also the rituals, values and actual embodyment and practice of these values. Religion links the physical and spiritual nature of man and has been considered to have a far-reaching impact on all aspects of an individual's life, including his achievement in the economic sphere. The positive values that religion or religiosity imbues in individual behavior such as honesty, accountability and other humane traits are considered to be pre-requisites for an individual's economic success. However, the accuracy of this notion needs to be examined.

Does religion or religiosity have an impact on individual economic achievement or progress? In the western context, Weber (1905/1930) views that religiosity can influence economic outcomes through fostering good traits such as work ethics, honesty, trust, thrift, charity, etc. Also, according to McCleary and Barro (2006, p. 51), the beliefs of different religions provide different economic incentives which result in different economic consequences. Galbraith and Galbraith (2007, p. 190) state that in the Christian tradition, there is a clear moral component of work and entrepreneurial effort which results in positive economic outcomes. Another view is that religiosity as related to church attendance may increase social capital. The networking and interaction effects may lead to economic opportunities resulting in higher income (McCleary \& Barro, 2006, p. 51). Although it may be argued that the other way around might also be true, i.e., high income enables people to have more free time, hence allowing them to frequent the church. However, such an argument is not very strong. Firstly, high income may or may not lead to more free time as individuals may find that they will need to work longer hours to continuously improve their economic condition. Secondly, even if they do have more free time they may not necessarily choose automatically to attend church more frequently.
However, an opposing view is that religiosity has a negative relationship with economic indicators as religion may reduce the utility derived from income (Bettendorf \& Dijkgraaf, 2005, p. 2).

The interest in the role of religion in economic development has generated a significant amount of empirical research. The studies that examine the relationship between religion or religiosity and economic variables have obtained mixed results. Some of these consider religion or religiosity as an explanatory variable and examine its impact on economic outcomes. For instance, the study by McCleary and Barro (2006, p. 66) finds that when "belief in hell" is used as a measure of religiosity, it is found to have a positive impact on GDP per capita. However, religiosity has a negative impact on GDP per capita if religiosity is measured by "monthly religious attendance". Some other studies highlight the positive contribution of religion and religiosity to economic achievement. Galbraith and Galbraith (2007, pp. 193-198) examine the relationship between religiosity, entrepreneurial activity, and economic growth. Religiosity is measured by three indicators - how important God is in one's life, whether one considers himself to be a religious person and the frequency of attending religious services. The findings suggest that religiosity is positively related to economic growth through the former's impact on entrepreneurial activity.

Similarly, the findings of Elçi, Sener, and Alpkan (2011, pp. 1367-1370) on employees working in manufacturing, service, and trade organizations in Turkey show that religiosity has a positive impact on work behavior. Their measure of religiosity includes (i) the strength of individuals' belief in God; (ii) the importance of religion and (iii) the individuals' perception of their level of religiosity.

Using World Values Survey data, Guiso, Sapienza, and Zingales (2003, p. 228 \& 280) find that, on average, religion is good for the development of attitudes such as cooperation, government, legal rules and market economy that are conducive to economic growth. However, they also highlight Islam as being negatively associated with attitudes that are conducive to growth and, among adherents to the world's major religions, Muslims as being the most anti-market. 
Other studies consider a two-way relationship between religiosity and economic outcomes. For instance, Bettendorf and Dijkgraaf (2005, p. 18) construct a simultaneous equation model using micro dataset for the Netherlands and find no significant relationship between religiosity, as measured by church attendance, and income. In another of their studies (Bettendorf \& Dijkgraaf, 2008, p. 23) based on data from 25 Western countries, the findings show that church membership has a positive effect on income for high-income countries, but negative effect for low-income countries.

On the other hand, the results derived from the study by Herzer and Strulik (2013, p. iii) indicate a more homogeneous relationship between religiosity and income. They find that a two-way negative relationship exists between the level of income, as measured by the log of GDP per capita, and the level of religiosity, as measured by church attendance. Higher income brings about declining religiosity, and declining religiosity leads to higher income.

Noland (2005, pp. 1215-1217) also considers the simultaneity between religiosity and two economic indicators, i.e., growth in total factor productivity (TFP) and real per capita income in his analysis. The findings based on both single-country and crosscountry analyses indicate that religious affiliation has a significant impact on economic growth. In addition, the variable 'Muslim population share' has a significant positive impact on TFP growth. He highlighted that this shows that belief in Islam is not inimical to growth.

Most of the empirical studies on the impact of religion on economic variables are conducted at a macro level and as cross-country analyses particularly for Western countries. Although many studies rely on survey data such as the World Values Survey to measure religiosity, the data for individuals is aggregated to represent country data. The latter is combined with other macroeconomic indicators such as per capita income to determine their relationship.

Studies that examine the influence of religiosity at a micro level are less common. Also, these studies suffer from a common limitation in that religiosity is measured by a very limited number of indicators. Religiosity is not just restricted to ritual practices. Rather, it encompasses an individuals' intensity of commitment to a religious belief system (McGuire, 1992, p. 108). The measurement of religiosity should be multi-dimensional and comprehensive to incorporate its various aspects. By doing this, the analysis would be more accurate and more reflective of the connection between religiosity and economic outcomes.

From the Islamic viewpoint, religiosity and economic development are closely related in a positive, direct and causal manner. This means that the level of economic achievement is highly dependent upon the practice of religion in the society concerned. This kind of positive relationship is declared by Allah Almighty in the Holy Qur'ān. Allah says ${ }^{(1)}$ :

If the people of the towns had but believed and feared Allah, We should indeed have opened out to them (all kinds of) blessing from heaven and earth; but they rejected (the truth), and We brought them to book for their misdeeds. (Qur'ān, 7:96)

This verse reveals one of the important divine laws (sunnä̈ Allah) pronouncing that the true religious practice would bring about economic development in the society and vice versa. As long as this religious factor exists, development would flourish. But conversely, if the former disappears, the latter would certainly collapse (al-Mudarrisy, 1985; Hamka, 1984; Shihab, 2004). Moreover, the Qur'ān (3:110) has even mentioned that the Muslim ummah is "the best ummah (society) evolved for mankind" which constitutes a model for the rest of the human society (Bakar, 2012, p. 445) for its commitment to enjoining the common good (al-ma'rüf), forbidding the bad things (al-munkar), and faith in Allah (al-īmān).

Therefore, it is very important to study how and to what extent the practice of Islamic religion (religiosity) is related to the development of Muslim countries or societies especially at a micro level. This paper examines whether religiosity is positively associated with high economic achievement for individuals, particularly in the case of South Kalimantan province, Indonesia. We attempt to address the measurement issues found in earlier studies by constructing a multi-dimensional measure of religiosity. This study considers five dimensions of religion,

(1) The analogous meaning can also be found in the following verses of the Holy Qur'ān: (Qur'ān, 2:268; 5:65-66; 16:30; $16: 97 ; 20: 132 ; 65: 2-4 ; 71: 10-12 ; 72: 16)$ 
namely: ritualistic, experiential, ideological, consequential and intellectual as suggested by Renzetti and Curran $\left(1998\right.$, p. 466) ${ }^{(2)}$. Ritualistic religiosity looks at the religious rites observed by a person such as attendance at the mosque, church or temple. Experiential religiosity measures how strongly a person feels attached to his or her religion. Ideological religiosity relates to the degree of commitment to religious doctrine or teachings. The extent to which religion affects the way a person conducts his or her daily life is best described as consequential religiosity. Intellectual religiosity measures a person's knowledge of the history and teaching of his or her religion. As the focus of this study is on Muslims, the measurement of each of these dimensions is viewed from the Islamic perspective. Islam does not oppose efforts to improve a person's economic position. In fact, it encourages seeking wealth; but it must be done according to the principles of Islam.

Abu Said related that the Prophet (may the peace and blessings of Allah be upon him) said: The truthful and trustworthy businessman will be in the company of the Prophets, saints and martyrs (on the Day of Judgment). (al-Darimi, 2000, 3:1653, hadith no. 2581; al-Tirmidhi, 1975, 3:507, hadìth no. 1209).

The analysis focuses on the effect of religiosity on economic achievement as positive values emphasized in religion are important in determining an individual's economic success. The study also examines the influence of religiosity on economic achievement of Muslims who live in the province of South Kalimantan, Indonesia. This province is of particular interest as its society is viewed as highly religious, but their economic performance is minimal relative to other provinces in the country. Islam has a long history in this province and has a major influence on many socio-cultural aspects of its society. Islam is adhered to by the majority of the people in this province $(96.67 \%)$ and its society has been observed to be highly religious and devoted to the Islamic teachings (Buseri, 2011; Daud, 1997). However, it is lagging with regards to development. The Human Development Index (HDI) for South Kalimantan has constantly been below the national average for the period of 2010 to 2015 (see Figure 1), ranking 22 out of 34 of the provinces in Indonesia in 2015. Similar is the case of GDP per capita as shown in Figure 2. For instance, this province recorded GDP per capita of 36.081 million Rupiah for 2016 which is far below the estimated national value of 47.957 million Rupiah. It would be interesting to determine if the observation of this community being highly religious is based more on the ritualistic aspects, or holistic. This can be examined from this study's multidimensional measure of religiosity. Also, it can be determined whether the level of religiosity is significantly associated with economic outcome or wellbeing.
(2) Renzetti and Curran's (1998) suggestion seems to have been taken from Charles Y. Glock's original idea as indicated in McGuire (1992, pp. 102-104). 
Figure (1) Human Development Index for South Kalimantan

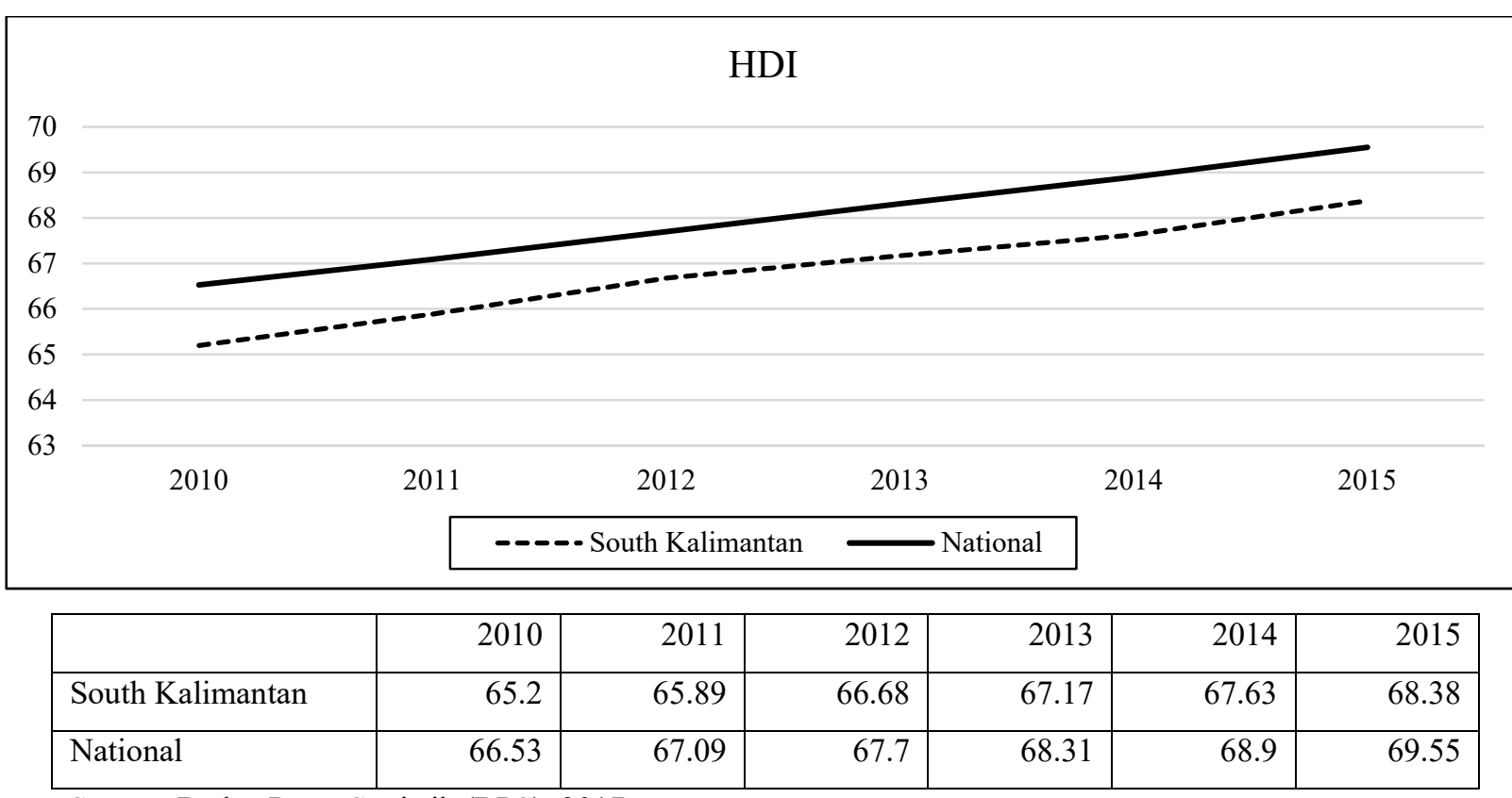

Source: Badan Pusat Statistik (BPS), 2017a

Figure (2) GDP per capita for South Kalimantan

\begin{tabular}{|l|l|}
\hline \multicolumn{1}{|c|}{ GDP per capita (Rp '000) } \\
60000 \\
50000 \\
40000 \\
30000 \\
20000 \\
10000 \\
0
\end{tabular}

Note: *estimated value

Sources: Statistical Yearbook of Indonesia 2017; BPS-Statistics Indonesia; https://www.bps.go.id/linkTableDinamis/view/id/957 
The paper proceeds as follows. In the next section, the construction of a multi-dimensional measure of religiosity is presented. This is followed by a descryption of the economic development indicators that are used in the analysis and the sample selection process and data that is used in this study. Section 3 comprises of the description of the sample and discussion of the findings. The summary and conclusion of the study is provided in Section 4.

\section{Methodology}

\subsection{Measure of religiosity: A multi-dimensional indicator}

Religiosity encompasses the belief system, acts of worship, moral and ethical values and conduct. Following Renzetti and Curran (1998, p. 466), it is represented by five dimensions which are ritualistic, experiential, ideological, consequential and intellecttual. As the data is collected through the use of a written questionnaire, all elements or items that represent each of the dimensions are constructed in the form of statements to be included in the questionnaire, and the responses are on a rating scale of 1 to 5 , either "totally disagree" to "totally agree"; or "never" to "always"(3). Each dimension is measured as the mean of the scores of the elements corresponding to that dimension. The religiosity measure is computed as the average score of the five dimensions. The value of the measure ranges from 1 (lowest religiosity) to 5 (highest religiosity).

The ritualistic dimension involves the particular set of religious practices, such as worship, obligatory prayer, fasting and the like, which are expected to be performed by the adherents. In Islam, there are obligatory and supererogatory rituals. In the measurement of preservation of religion, this study focuses on only the obligatory ones. The obligatory rituals include obligatory șalāh five times a day, siyām (fasting) in the month of Ramaḍan, the Friday prayer (salāh) for an adult man, and wearing of hijāb (veil) for adult women. Performing hajj is one of the main pillars in Islam. However, it is obligatory only for those who can afford to do so. Hence, this is excluded from the analysis. As for zakāh, since it requires the fulfilment of nișāb (minimum amount in possession) for a complete lunar year (hawl) to qualify for its payment, it is also excluded since there is difficulty in determining whether the respondents fulfill the requirements for paying zakāh.

Experiential dimension relates to feelings, perceptions, and sensations of having communication with Allah and involvement in religious activities/organizations. Religious practices that provide opportunities to be closer to Allah such as seeking Allah's forgiveness and purification of the soul and heart from sins, performing șala $h$ with full devotion, and involvement in preaching activities and other religious activities are considered in the measurement of this dimension. The ideological dimension covers the faith that is expected to be believed by the adherents. The elements involved in the measurement of this dimension are the importance of religion in one's life, giving precedence to religion over other matters, and to believe in the Divine will and decree.

The effects of religious belief, practice, experience, and knowledge on the adherent's everyday life define the consequential dimension. It is reflected in the daily life of Muslims in terms of how they view morality in the changing world, whether religious beliefs should be compromised to attain selfinterest, and whether attaining earnings can be from non-permissible means. These three indicators are used to measure this dimension. The intellectual dimension refers to basic information and knowledge about the religion that is expected to be known by the adherents. This study considers three items to represent this dimension, namely, sparing some time to learn about religion, understanding the meaning of the Qur'ānic verses, and having interest in discussions about religion. Table 1 provides a summary of the dimensions and elements of religiosity.

(3) Some of the statements are written in negative form and the responses are accordingly reversely scored. 
Table (1) Dimensions and Elements/Items of Religiosity

\begin{tabular}{|l|l|}
\hline Dimension & \multicolumn{1}{|c|}{ Element/Item } \\
\hline \multirow{4}{*}{ Ritualistic } & Performing obligatory prayers \\
\cline { 2 - 2 } & Performing Friday prayers (men)/wearing hijab (women) \\
\cline { 2 - 2 } & Fasting in Ramad̦ān \\
\cline { 2 - 2 } & Reciting the Qur'ān \\
\hline \multirow{4}{*}{ Experiential } & Seeking God's forgiveness for wrongdoings \\
\cline { 2 - 2 } & Performing prayers with full devotion \\
\cline { 2 - 2 } & Involvement in preaching activities and other religious movements \\
\hline \multirow{4}{*}{ Ideological } & Importance of God \\
\cline { 2 - 2 } & Religion as a guidance \\
\cline { 2 - 2 } & Whether other things in life are more important than religion \\
\cline { 2 - 2 } & Believe in the Divine will and decree. \\
\hline \multirow{3}{*}{ Consequential } & View of morality in the changing world \\
\cline { 2 - 2 } & Religious beliefs can be compromised to attain self-interest \\
\cline { 2 - 2 } & Attaining earnings from non-permissible means \\
\hline \multirow{2}{*}{ Intellectual } & Making time to learn about the religion \\
\cline { 2 - 2 } & Understanding the meaning of the Qur'ānic verses \\
\cline { 2 - 2 } & Having interest in discussions about religion \\
\hline
\end{tabular}

\subsection{Measures of individual economic achievement: Income and economic wellbeing}

In this study, two measures of economic achievement are considered. The first is monthly income of the individuals. The construction of the second measure is based on the definition of economic wellbeing from an Islamic perspective. It is extracted from the work by Amin, Yusof, Haneef, Muhammad, and Oziev (2015, pp. 165-166) which uses the maqāsid al-Sharī ah framework and applies content analysis to derive the operational definition of preservation and development of wealth. It is defined as the protection of ownership and property from damage, harm, theft, exploitation or injustice. Also, it encompasses the acquisition and development of wealth by making it available through circulation and equitable distribution, as well as preserving the wealth through investment and good governance. There are five dimensions that correspond to it: (i) protection of ownership and property; (ii) protection of wealth and property from damage or harm; (iii) preservation of wealth through protection of its value; (iv) preservation of wealth through its circulation; and (v) acquisition and development of property and wealth.

Although there are five dimensions for this definition, this study focuses only on the last dimension, which relates to the maintenance or upkeep of daily or routine economic wellbeing. Specifically, the second measure of economic wellbeing is constructed based on individuals' responses on a rating scale of 1 ("totally disagree") to 5 ("totally agree") to three statements: (i) having a stable income; (ii) having sufficient income; and (iii) having financial investment(s). The mean score from these three items, which ranges from 1 to 5, represents the level of economic wellbeing. Higher values indicate higher wellbeing and therefore higher economic achieve-ment, and lower values correspondingly reflect lower economic achievement.

\subsection{Sample selection and data}

Data is obtained from a random sample of individuals in South Kalimantan, Indonesia. This province is situated in the southern Kalimantan Island and covers an area of around $37,530.52 \mathrm{~km}^{2}$ or about $6.98 \%$ of the total size of the island. Administratively, this province consists of 13 districts (11 regencies and 2 municipalities), 152 subdistricts, and 2,008 villages. Banjarmasin is the capital city of the province. The population of South Kalimantan in 2016 was 4,055,479, of which 96.67 percent were Muslims (Badan Pusat Statistik [BPS], 2017b).

The selection of sample is based on a multistage sampling technique. Firstly, the 13 districts are placed in one of three groups, high, medium or low, according to their Human Development Index (HDI) 
score. The districts of Banjarmasin (high), Banjar (medium), Balangan (low) and Hulu Sungai Tengah (low) are chosen to represent the three groups. The second stage is choosing one urban and one rural subdistrict from each district. The third stage involves a random selection of two to five villages from each sub-district, and from each village, a neighborhood is randomly chosen. The selection of individuals is based on the households they live in. Thus, the final stage is the random selection of households in the selected neighborhood.

The head, or in cases of him/her being absent, the spouse or another adult person in the household, was required to complete a written questionnaire. Out of 500 adult individuals representing households that were included in the sample, the study obtained responses from 461. However, this study includes only those who earn a positive monthly income ${ }^{(4)}$, resulting in 373 usable responses.

\section{Results and Discussion}

\subsection{Sample description}

The sample individuals, as presented in Table 2, are made up of 32.4 percent females and 67.6 percent males, and over 86 percent are married. Almost all of the male respondents are head of households compared to less than a quarter $(24.8 \%)$ for female respondents. The majority of the sample have secondary education and earn income less than Rp 2,500,000. In this sample, women are more in the younger age groups compared to men. The location where the individuals live is about equally distributed between urban and rural areas.

Table (2) Description of Sample

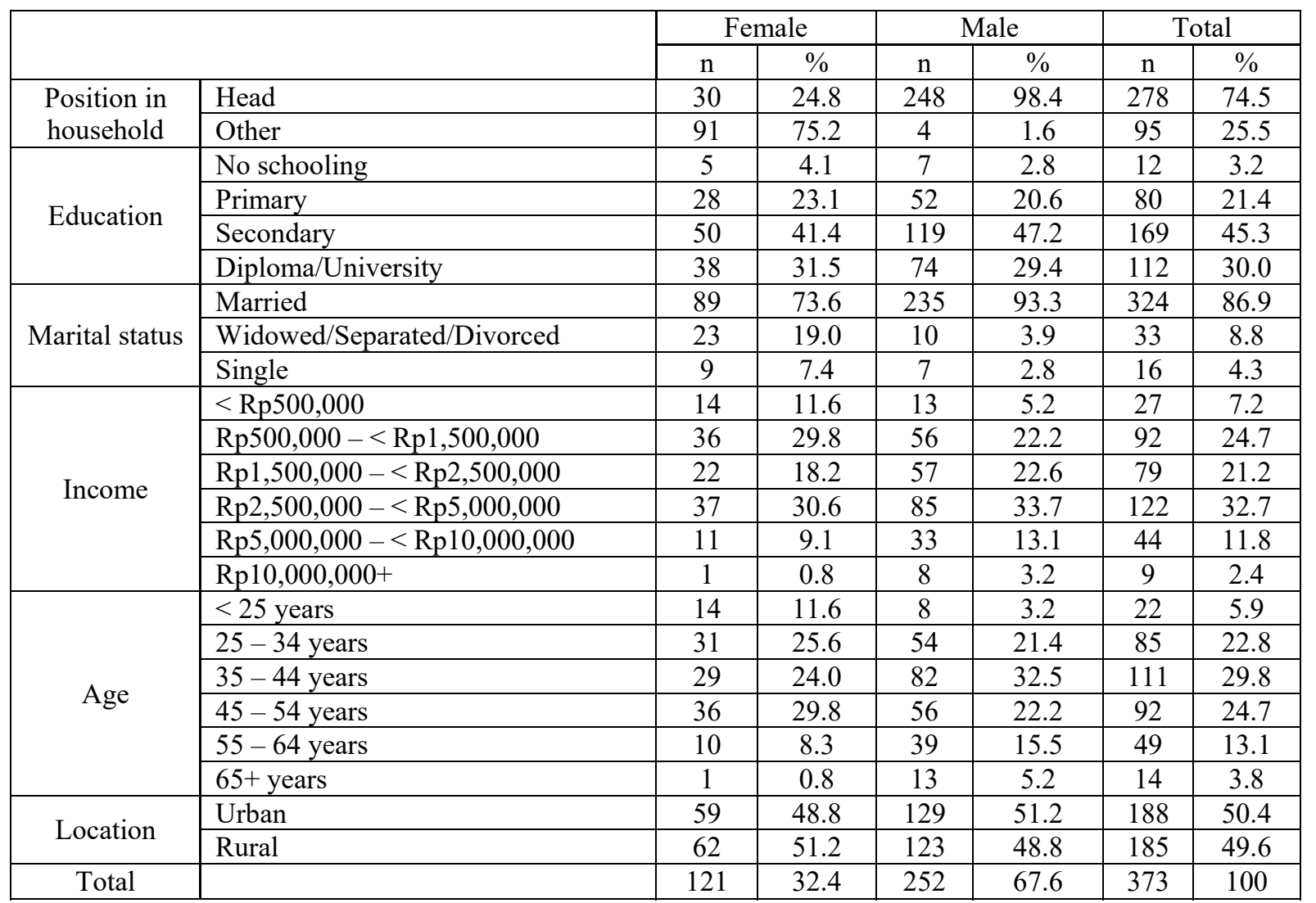

(4) This study includes only those with positive monthly income as the dependent variable is log of income. For consistency and comparison purposes, the same sample is used for the analysis using the second measure of economic achievement indicator as the dependent variable. 


\subsection{Level of religiosity and individual economic achievement}

Table 3 presents the levels of religiosity, monthly income, and economic wellbeing. The constructed religiosity measure ranges from 1 (lowest religiosity) to 5 (highest religiosity). Based on the findings, the religiosity scores are negatively skewed, with a mean value of 4.004, indicating a relatively high religiosity level, on average. This result is consistent with the observation that the people of South Kalimantan are religious. Nevertheless, the range of the scores is from 1.722 to 4.944 , indicating different levels of religiosity, where there are individuals especially among men who have relatively low religiosity levels. However, t-test on differences of means indicates no significant difference in religiosity between men and women, on average (t-value of 0.001 with p-value of 0.999 ).

Table (3) Religiosity and Economic Development Levels

\begin{tabular}{|c|c|c|c|}
\hline & Religiosity & Monthly income (Rp) million) & Economic wellbeing \\
\hline \multicolumn{4}{|c|}{ All } \\
\hline Mean & 4.004 & 2.740 & 3.388 \\
\hline Median & 4.056 & 2.100 & 3.333 \\
\hline Minimum & 1.722 & 0.030 & 1.000 \\
\hline Maximum & 4.944 & 21.000 & 5.000 \\
\hline Std Deviation & 0.532 & 2.485 & 0.857 \\
\hline $\mathrm{n}$ & 373 & 373 & 373 \\
\hline \multicolumn{4}{|c|}{ Female } \\
\hline Mean & 4.004 & 2.227 & 3.438 \\
\hline Median & 4.056 & 1.900 & 3.333 \\
\hline Minimum & 2.556 & 0.030 & 1.000 \\
\hline Maximum & 4.944 & 10.000 & 5.000 \\
\hline Std Deviation & 0.422 & 1.886 & 0.863 \\
\hline $\mathrm{n}$ & 373 & 373 & 373 \\
\hline \multicolumn{4}{|c|}{ Male } \\
\hline Mean & 4.004 & 2.986 & 3.364 \\
\hline Median & 4.111 & 2.490 & 3.333 \\
\hline Minimum & 1.722 & 0.200 & 1.333 \\
\hline Maximum & 4.944 & 21.000 & 5.000 \\
\hline Std Deviation & 0.578 & 2.695 & 0.854 \\
\hline $\mathrm{n}$ & 252 & 252 & 252 \\
\hline
\end{tabular}

The mean monthly income ranges from $\mathrm{Rp} 0.03$ million to $\mathrm{Rp} 21$ million with a mean of $\mathrm{Rp} 2.74$ million, and the distribution is positively skewed, as expected. T-test reveals that women earn significantly lower than men. Based on this measure, women have a lower level of economic achievement compared to men. However, from the economic wellbeing aspect, both men and women are in good position, recording scores of 3.438 and 3.364, respectively, which are significantly higher than the satisfactory score of 3 (the t-values for testing mean scores larger than 3 are 5.584 and 6.759 for women and men, respectively). In addition, the economic wellbeing of women is not significantly different from that of men.

\subsection{Relationship between religiosity and individual economic achievement}

Regression analyses are conducted to determine the impact of religiosity on economic achievement of individuals. The study also included several personal characteristics in the regression equation as control variables. Age, which to some extent reflects working 
experience, and educational level are human capital indicators which are expected to have a positive impact on the economic condition of individuals. The variable education assumes a value from 1 (no schooling) to 7 (post-graduate degree). The third control variable is a dummy variable to differentiate between those living in urban and non-urban areas. There may be differences in the economic achievement between those living in urban areas as compared to others as economic opportunities are expected to be more in urban areas. The study also considers two other variables: marital status and whether the individual is a head of household or not, as these factors may impact the motivation for, and hence the level of, economic achievement. The reference category for marital status is divorced, separated or widowed. Gender is included to determine if there are differences between men and women as suggested from the preliminary analysis, once other factors are controlled for.

For the regression analyses, two economic development measures, total monthly income (in logarithm) and the level of economic wellbeing are the dependent variables. Ordinary Least Squares (OLS) regressions are estimated for the combined sample of men and women, and separately for men and women. Diagnostic tests on specification, multicollinearity, heteroscedasticity and normality are performed on the regression equations. The results are shown in Table 4.

There are no indications of specification error based on Ramsay RESET test. In addition, although the variable Head appears to be somewhat correlated with other explanatory variables, the test indicates that there is no problem of serious multicollinearity between the explanatory variables (the variance inflating factors (VIF) are all less than 5). Estimations omitting the variable Head produce qualitatively similar results (as the results are qualitatively similar, they are not reported in this paper). All the models have homoscedastic errors with the exception of one. The regression for log of income for the joint sample of men and women indicates the presence of heteroscedasticity (based on White test). White heteroscedasticity consistent standard errors and covariance are used to address this issue. This regression, and the regression for the women sample are found to have residuals that are not normally distributed (based on Jarque-Bera tests). As the sample is large, the occurrence of non-normality is tolerated in this analysis.

The results, as shown in Table 4 indicate that religiosity has a significant positive impact on economic wellbeing. Those with higher religiosity experience higher levels of wellbeing in terms of having sufficient and stable income, and having financial investments. Religiosity is also significantly positively related to income for men, but there is no significant relationship between religiosity and income for women. Thus, religiosity is not an impediment to economic progress as found by some studies especially those related to Muslims. Rather, it contributes positively to the economic achievement of individuals and hence to the society. 
Table (4) Determinants of economic development: income and economic wellbeing

\begin{tabular}{|l|c|c|c|c|c|c|}
\hline & \multicolumn{2}{|c|}{ All (n=373) } & \multicolumn{2}{c|}{ Men (n=252) } & \multicolumn{2}{c|}{ Women (n=121) } \\
\hline & Log(income) & Econ Wellbeing & Log(income) & Econ Wellbeing & Log(income) & Econ Wellbeing \\
\hline Age & $0.012^{* * *}$ & -0.005 & $0.005^{*}$ & $-0.008^{* *}$ & $0.033^{* * *}$ & 0.006 \\
\hline Male & 0.182 & 0.168 & & & & \\
\hline Urban & $0.397^{* * *}$ & 0.096 & $0.345^{* * *}$ & $0.162^{* *}$ & $0.544^{* * *}$ & -0.016 \\
\hline Education & $0.259^{* * *}$ & $0.074^{* * *}$ & $0.272^{* * *}$ & $0.076^{* * *}$ & $0.272^{* * *}$ & $0.069^{*}$ \\
\hline Head & 0.093 & $-0.325^{* *}$ & $-0.704^{*}$ & $-0.840^{*}$ & 0.271 & -0.191 \\
\hline Married & $0.257^{*}$ & -0.050 & 0.218 & -0.047 & $0.690^{* *}$ & 0.182 \\
\hline Single & 0.018 & $-0.416^{*}$ & $-0.749^{* *}$ & $-0.776^{*}$ & $0.757^{*}$ & -0.092 \\
\hline Religiosity & $0.124^{*}$ & $0.714^{* * *}$ & $0.149^{* *}$ & $0.673^{* * *}$ & 0.015 & $0.890^{* * *}$ \\
\hline Constant & $11.849^{* * *}$ & $0.581^{*}$ & $13.018^{* * *}$ & $1.538^{* *}$ & 10.908 & -0.691 \\
\hline R-squared & 0.362 & 0.296 & 0.417 & 0.305 & 0.283 & 0.314 \\
\hline Diagnostics & $\checkmark$ & $\checkmark$ & $\checkmark$ & $\checkmark$ & $\checkmark$ \\
\hline Specification & $\checkmark$ & $\checkmark$ & $\checkmark$ & $\checkmark$ & $\checkmark$ & $\checkmark$ \\
\hline No multicollinearity & $\checkmark$ & $\checkmark$ & $\checkmark$ & $\checkmark$ & $\checkmark$ & $\mathbf{x}$ \\
\hline Normality & $\mathbf{x}$ & $\checkmark$ & $\checkmark$ & $\checkmark$ & $\checkmark$ & $\checkmark$ \\
\hline Homoscedasticity & $\mathbf{x}$ & $\checkmark$ & $\checkmark$ & & \\
\hline
\end{tabular}

$*, * *, * * *$ significant at $10 \%, 5 \%$ and $1 \%$, respectively.

An interesting finding is that among men, although the older ones attain higher income, their economic wellbeing is lower. Older men may have more responsibilities and dependents and thus their higher income may be insufficient to fulfill those needs. Those living in urban areas make more money, and for the men, they enjoy a higher level of economic wellbeing. Men who are heads of households also earn lower income and experience a lower level of wellbeing. Women who are widowed, divorced or separated earn lower income than other women. However, they do not differ from others in terms of stability and adequacy of income, and ownership of financial investment.

An encouraging result is that education plays a significant positive role in contributing towards economic development. Individuals with higher education levels do better in terms of income and economic wellbeing. The analysis also shows that after controlling for other factors, women and men are equal in their economic achievement.

\section{Summary and Conclusion}

This study provides a novel way to measure Islamic religiosity among individuals. In addition, this paper constructed an indicator other than income to reflect economic achievement. The economic wellbeing indicator reflects individuals' level of adequacy and stability of income, and investment to meet current and future financial needs. Those with higher scores on this indicator exhibit higher economic wellbeing, that is, they are more financially and economically developed.

These two measures of economic achievement are used to determine the effect of religiosity on the people of South Kalimantan. Consistent with the Islamic ideology that Islam strongly promotes development (Sulaiman, 2008), the analysis shows that religiosity contributes positively to economic achievement. Muslims in South Kalimantan have a relatively high level of religiosity, and those with higher religiosity are economically better-off.

The suggestion of the negative association between religion and economic development especially for the people of South Kalimantan is shown to be otherwise in general. In fact, even if only income is considered to reflect economic achievement, it is positively related to religiosity for the sample of men in this study. Nonetheless, there are determinants other than religiosity that impact individual economic development. Education, for instance, is found to be a significant determinant of economic development. The low level of education among the South Kalimantan community is one of the important factors that leads to low economic achievement. In fact, based on the latest population census, more than 30 percent of the South Kalimantan people did not complete primary school (BPS, 2010). Therefore, it can never be over-emphasized that education must be one of the main focus of policy to achieve economic progress. 
The findings of this study support the importance of religiosity as it can bring about economic prosperity and wellbeing. Religiosity is not just about performing the rituals, but the embodiment and understanding of religion which encompasses the

\section{References}

Amin, R.M., Yusof, S.A., Haneef, M.A., Muhammad, M.O., \& Oziev, G. (2015). The Integrated Development Index (I-Dex): A new comprehensive approach to measuring human development. In Hatem A. El-Karanshawy, Azmi Omar, Tariqullah Khan, Salman Syed Ali, Hylmun Izhar, Wijdan Tariq, ... Bahnaz Al Quradaghi (Eds.), Islamic Economics: theory, policy and social justice, developing inclusive and sustainable economic and financial systems (vol. 2, pp. 159-171). Doha, Qatar: Bloomsbury Qatar Foundation.

Bakar, Osman (2012). The Qur'ānic Identity of the Muslim Ummah: Tawhidic Epistemology as Its Foundation and Sustainer. Islam and Civilisational Renewal, 3(3), 438-454.

Bettendorf, L., \& Dijkgraaf, E. (2008). Religion and income: heterogeneity between countries (Tinbergen Institute Discussion Paper No. 2008-014/3). Retrieved from: https://papers.tinbergen.nl/08014.pdf

Bettendorf, L., \& Dijkgraaf, E. (2005). The bicausal relation between religion and income (Tinbergen Institute Discussion Paper No. 05-105/2). Retrieved from: https://papers.tinbergen.nl/05105.pdf

Badan Pusat Statistik [Central Bureau of Statistics]. (2010). Sensus Penduduk 2010 [Population Census 2010]. Jakarta: Author.

Badan Pusat Statistik [Central Bureau of Statistics]. (2017a). Indeks Pembangunan Manusia IPM Kalimantan Selatan 2010-2016 [Human Development Index HDI South Kalimantan 2010-2016]. Retrieved from: https://kalsel.bps.go.id/linkTableDinamis/view/id/831

Badan Pusat Statistik [Central Bureau of Statistics]. (2017b). Jumlah Penduduk Menurut Kabupaten/Kota dan Jenis Kelamin Tahun 2003-2020 [Total Population by Regency/City and Sex Year 2003-2020]. Retrieved from: https://kalsel.bps.go.id/linkTableDinamis/view/id 1875

Buseri, K. (2011, December). Budaya spiritual Kesultanan Banjar: Historisitas dan relevansinya di masa kini [The spiritual culture of the Banjari Sultanate: History and its contemporary relevance]. Paper presented at the Seminar Penguatan Budaya Banjar dan Peran Kesultanan dalam Menjawab Tantangan Zaman [Seminar on the Enhancement of Banjari Culture and the Role of the Sultanate in Addressing Contemporary Issues], 8 December, Banjarmasin, Indonesia.

al-Darimi, Muhammad bin Abdullah (2000). Sunan alDarimi. Riyadh: Dar al-Mughni.

Daud, A. (1997). Islam dan masyarakat Banjar: Deskripsi dan analisa kebudayaan Banjar [Islam and the Banjari belief system, acts of worship and moral and ethical values and conduct. If individuals abide by these principles, then it will translate into economic and non-economic success in their lives.

Society: Description and analysis of the Banjari Culture]. Jakarta: Rajawali Press.

Elçi, M., Sener, I., \& Alpkan, L. (2011). The impact of morality and religiosity of employees on their hardworking behavior. Procedia - Social and Behavioral Sciences, 24, 1367-1377.

Galbraith, C.S., \& Galbraith, D.M. (2007). An empirical note on entrepreneurial activity, intrinsic religiosity and economic growth. Journal of Enterprising Communities: People and Places in the Global Economy, 1(2), 188-201.

Guiso, L., Sapienza, P., \& Zingales, L. (2003). People's opium? Religion and economic attitudes. Journal of Monetary Economics, 50, 225-282.

Hamka, Haji Abdul Malik Karim Amrullah (1984). Tafsir Al-Azhar. Singapura: Pustaka Nasional.

Herzer, D., \& Strulik, H. (2013). Religiosity and Income: A Panel Cointegration and Causality Analysis (Center for European Governance and Economic Development Research Discussion Paper No. 168). Retrieved from: https://www.econstor.eu/bitstream/10419/79223/1/757 203477.pdf

McCleary, R. M., \& Barro, R. J. (2006). Religion and economy. Journal of Economic Perspectives, 20(2), 49-72.

McGuire, M.B. (1992). Religion: The Social Context (3rd ed.). Belmont, Ca.: Wadsworth Inc.

al-Mudarrisy, Muhammad Taqi (1985). Tafsir min huda al-Qur'ān. Beirut: Darul Huda.

Noland, M. (2005). Religion and economic performance. World Development, 33(8), 1215-1232.

Quinn, P. (2005). Philosophy of religion A-Z. Edinburgh: Edinburgh University Press.

Renzetti, C., \& Curran, D. (1998). Living Sociology. Boston: Allyn \& Bacon.

Shihab, M. Q. (2004). Tafsir Al-Mishbah: Pesan, kesan, dan keserasian Al-Qur'an [Messages, infuence and compatibility of the Qur'ān]. Jakarta: Lentera Hati.

Sulaiman, K. (2008). The role and significance of religion in human life with particular emphasis on Islam. International Journal of Muslim Unity, 6(1/2), 5-60.

al-Tirmidhi, Muhammad bin Eisa. (1975). Sunan alTirmidhi. Cairo: Maktabah wa Matba'ah Mustafa alBabi al-Halabi.

Weber, M. (1930). The Protestant Ethic and the Spirit of Capitalism (T. Parsons, Trans.). London: Allen \& Unwin. (Original work published in 1905)

Wilson, J.F., \& Slavens, T.P. (1982). Research guide to religious studies. Chicago: American Library Association. 
Selamah Abdullah Yusof is a professor at the Department of Economics and Research Fellow at the Centre for Islamic Economics, International Islamic University Malaysia (IIUM). She obtained her PhD degree in economics from Purdue University, U.S.A. Her research interests include: household economics behavior, labor economics, values and socioeconomic development, and examining areas in economics from an Islamic perspective. She was appointed as the Head of Department of Economics in 1999 and served in that position until 2003. She was the Editor of IIUM Journal of Economics and Management (currently known as the International Journal of Economics, Management \& Accounting) for 2004-2005, and was also an editorial board member of Asian Academy of Management Journal from 2003 to 2006. She has been a reviewer for various journals including Social Indicator Research, Journal of Family and Economics Issues, and International Journal of Social Economics.

E-mail: selamah@iium.edu.my

Mohammad Arif Budiman graduated with a Bachelor's degree from the Faculty of Shariah, the State Islamic University Sunan Kalijaga, Yogyakarta, Indonesia (2000) and received his master degree (Islamic Economics) from the State Islamic University Sunan Ampel, Surabaya, Indonesia in 2002. Since then, he has been a teaching staff and researcher at the study program of Accounting for Islamic Financial Institutions at Banjarmasin State Polytechnic (Politeknik Negeri Banjarmasin), South Kalimantan, Indonesia. He is currently completing his $\mathrm{PhD}$ from the Department of Economics, Kulliyyah of Economics and Management Sciences, International Islamic University Malaysia (IIUM), Kuala Lumpur. He served as a Research Assistant at IIUM from 2012-2016. His PhD research has been funded by Graduate School of Management Research Fund (GSMRF), IIUM. He has also obtained several research grants from the Ministry of Research, Technology and Higher Education, Republic of Indonesia (20152018). His areas of interest include: Islamic economics, Islamic studies, religiosity, zakäh, and waqf.

E-mail: mab.iium@gmail.com

Ruzita Mohammad Amin obtained her BSc (Hons.) in Economics from the International Islamic University Malaysia (IIUM), her M.A. (Economics) from Northwestern University, USA, and her $\mathrm{PhD}$ (Managerial Economics), from Rensselaer Polytechnic Institute, USA. She has served at IIUM since 1987, and currently she is a Professor at the Department of Economics and Research Fellow at the Centre for Islamic Economics, IIUM. She was Deputy Dean (Academic) of the Kulliyyah of Economics \& Management Sciences from 2005 to 2007 and currently she is the Head of the Disability Services Unit, IIUM. She was Editor of the IIUM Journal of Economics \& Management (currently known as the International Journal of Economics, Management \& Accounting) for the periods 1995-2004 and 2008-2011. Her research interests include: development economics, economic integration, economic theory from the Islamic perspective, disability studies and social economics.

E-mail: ruzita@iium.edu.my 


\title{
العلاقة بين التدين والإنجاز الاقتصيادي للأفراد: أدلة من جنوب كاليمانتان، إندونيسيا
}

\author{
سلامة عبدالله يوسف \\ كلية الاقتصاد، الجامعة الإسلامية العالمية ، ماليزيا \\ محمد عارف بوديمان \\ كلية المحاسبة للمؤسسات المالية الإسلامية، جامعة بانجارماسين الوطنية، إندونيسيا \\ روزيتا محمد أمين \\ كلية الاقتصاد، الجامعة الإسلامية العالمية، ماليزيا
}

المستخلص. تتناول هذه الدراسة تأثير التََّين على النمو أو الإنجاز الاقتصادي للأفراد في مقاطعة

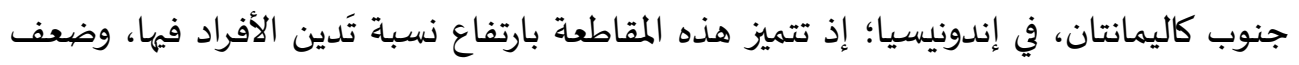

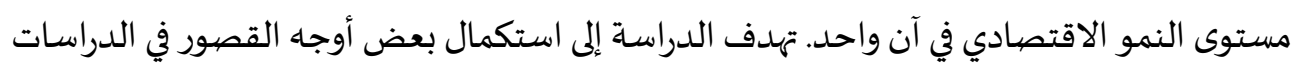

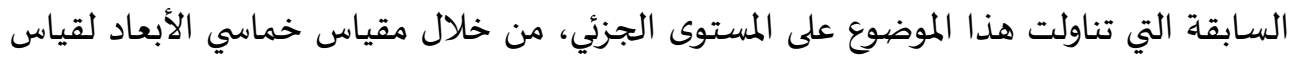

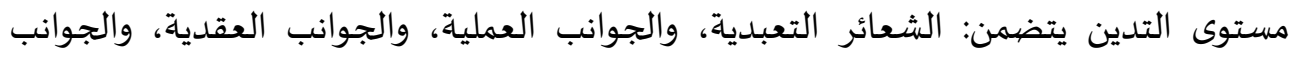

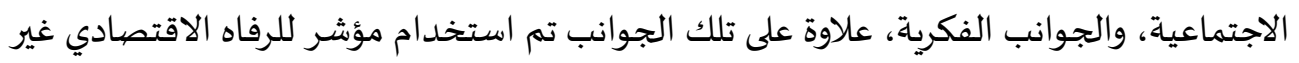

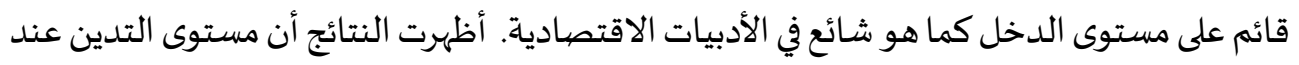

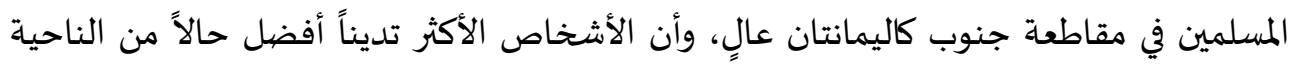

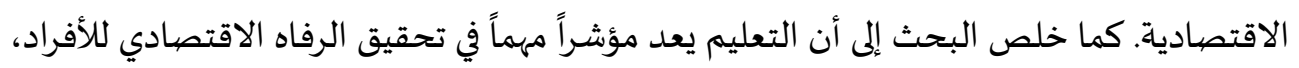

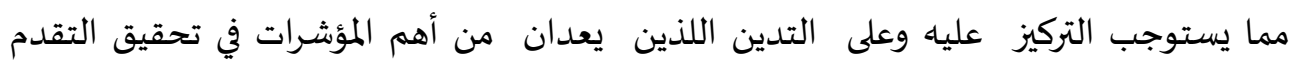
الاقتصادي خاصة في مقاطعة جنوب كاليمانتان ذات الطبيعة السكانية الأقل تعليماً.

$$
\text { تصنيف A12, A13, 012, Z12 :JEL الكلمات الدَّالة: التدين، كاليمانتان الجنوبية، الإنجاز الاقتصادي. }
$$

